\section{The (Restored) Practice of DEFA Co-productions with "Normalized" Czechoslovak Film Studio in the 1970s}

The DEFA-Stiftung website provides an enormous amount of substantive information on the studio. This prominent site presenting the studio's history is headlined by three pictures: next to the couple from the Gegenswartfilm by Heiner Carow Die Legende von Paul und Paula (1972), we can see Gojko Mitić in an Indianerfilm (a super-successful genre series whose first instalment was directed by the Czech Filmmaker Josef Mach) and an image from the DEFA-Barrandov coproduction Drei Haselnüsse für Aschenbrödel. These images suggest that these movies, which were made as a cooperation between the Czech and the German studios, continue to play a highly significant role in constructing DEFA's "cultural heritage". In this paper, I will focus on the mode of cooperation the two studios established in the 1970s and consider the reasons for their realignment after a cooling period in the cultural relations between these countries during the late 1960s, and how they profited from this renewed collaboration.

During the 1970s, the East German DEFA Studios and the Czech Barrandov Studios cooperated on 7 nominal co-productions:

- Die gestohlene Schlacht/Ukradená bitva, 1971, dir. Erwin Stranka (historical comedy)

- Die Elixiere des Teufels/Elixíry dábla, 1972, dir. Ralf Kirsten (adaptation of an E.T.A. Hoffmann novel)

- Schüsse in Marienbad/Výstřely v Mariánských Lázních, 1973, dir. Ivo Toman (political drama)

- Drei Haselnüsse für Aschenbrödel/Tři ořišky pro Popelku, 1973, dir. Václav Vorlíček (fairytale)

- Abenteuer mit Blasius/Dobrodružstvís Blasiem, 1974, dir. Egon Schlegel (children's movie)

- Die Insel der Silberreiher/Ostrov stř́brných volavek, 1976, dir. Jaromil Jireš (children's movie)

- Der Katzenprinz/Kočičí princ, 1979, dir. Ota Koval (fairytale)

Also during that decade, DEFA made another 8 co-productions, 3 of them with the USSR, and Barrandov made another 15 co-productions, 7 of them with the USSR. This meant that each of the studios made roughly one-third of their co-productions deals with each other. This level of cooperation is matched by no other except the Soviets (projects were also shared with other Soviet studios, the most active of which was Mosfilm, with 6 co-productions), and is in striking contrast
Images vol. XIII/no. 22 Poznań 2013 ISSN 1731-45OX
From war to skates the first era of co-productions 
with the period from 1966 to 1970, when no nominal co-productions between DEFA and Barrandov were carried out at all. What were the reasons for such close collaboration in the 1970s, and the rather abrupt re-rapprochement of DEFA and Barrandov after a five-year-long break? To answer the question satisfactorily, we should start with a look backward into the 1960 s.

To do this, let me summarize my previous research into DEFA-Barrandov cooperation up until the 1970s. The first Barrandov-DEFA co-production, Jahrgang 21 (Ročník 21; dir. Václav Gajer, 1957), was sustained by DEFA's need to balance its co-productions with West Germany. For "strategic" reasons, in May 1955 the head of the East German Central Film Administration (Hauptverwaltung Film) Anton Ackermann proposed a co-production project to Czechoslovak State Film (Československý státní film - ČSF) representatives. According to Ackermann, the Socialist Unity Party of Germany (Sozialistische Einheitspartei Deutschlands - SED) preferred co-productions with socialist countries; yet a first co-production with the Soviets was not within easy reach, and "the situation when DEFA makes co-productions with capitalist partners but none with the friendly socialist countries as Czechoslovakia or Poland is no longer acceptable." [1]

Slow-paced co-operation continued, with one children's movie (Die Igelfreundschaft/Uprchlik, dir. Hermann Zschoche, 1961), and a literary adaptation dealing with common German-Czech fascist resistance (Koffer mit Dynamit/Praha nultá hodina; dir. Miloš Makovec, 1963) being made. However, it was the first entertainment genre picture, the musical Eine schreckliche Frau (Strašná žena; dir. Jindřich Polák, 1965), which marked a shift in the mode of cooperation. The project was explicitly conceived as intended for export, but among the capitalist countries only Italy bought the movie from the Czechoslovak export company Filmexport, and attendance in Czech cinemas reached 664,000 viewers till 1970, which was a mediocre result.[2] Film critics were not very enthusiastic about the movie, neither in GDR, nor in Czechoslovakia.[3] Despite these dubious results, the co-production was rather significant for its strong genre identity as well as for the motivations on both sides of the partnership. The director of Barrandov Studio Vlastimil Harnach conditioned the project's approval on the requirement that DEFA had to ensure colour material as well as

[1] Quoted in a report from the Czechoslovak embassy in Berlin to the Ministry of Culture and the Ministry of Foreign affairs, May 12, 1955. Archive of the Ministry of Foreign Affairs in Prague (AMZV), TO obyčejné, 1945-1959, NDR, k. 27 - osvěta. The urgency of the socialist co-production partnership originated in the DEFA's cooperation with $\mathrm{Mu}$ nich-based producer Erich Mehl and his company Pandora, based in Stockholm.

[2] J. Havelka, Čs. filmové hospodárství 1961-1965,
Československý filmový ústav, Praha 1975, p. 250; J. Havelka, Čs. filmové hospodářství 1966-70, Československý filmový ústav, Praha 1976, p. 259. [3] See, e.g., A.J. Liehm, "Orientace našeho filmu," Literární noviny 14, 1965, p. 8; G. Francl, "Strašná žena/Délka polibku devadesát/Perlový náhrdelník," Kino 20, 1965, p. 5; G. Focke, "Erschrecken über 'Eine schreckliche Frau,' Freiheit, August 9,1965; R. Seydel, "Eine Schwalbe macht noch keinen Sommer," Filmspiegel 17, 1965, p. 9. 
widescreen cameras. [4] The demand reveals Barrandov's incentives for making the movie with DEFA even though Barrandov perceived DEFA as a conservative studio and was not very enthusiastic about mutual co-productions as being anything more than a way to share investment costs. The Czech studio approached DEFA more as a useful vehicle for negotiating with West German producers, than as a viable partner.[5] The implications of the common project on the side of DEFA seem to be even straighter: passive financial and creative participation in a movie which it viewed favourably, as it belonged to an entertainment genre which had a long and successful tradition in Germany. For DEFA studios, the project represented the first step towards a new strategy for coping with a lack of creative individuals with experience producing genre movies, or who were at least willing to deal with entertainment production during the rather liberal period that briefly preceded the infamous attack by Socialist Unity Party functionaries on the cultural sphere during the 11th Plenum of the Central Committee of the SED (Kahlschlag). The production of the movie indicates quite a lot about the strategies, plans, and troubles the DEFA had making genre productions in the mid 196os.[6]

It was after this promising start that the five-year hiatus in DEFA-Barrandov co-productions took place. The period from 1966 to 1970 was highly significant for both the GDR and the Czechoslovakia, as well as for their film industries. At Barrandov during this period, the Czech New Wave experienced its heyday, and the studio shot 9 movies with western partners. DEFA, in contrast, had to cope with effects of the 1965 Kahlschlag, which were devastating for the artistic endeavours of GDR filmmakers, but did not prevent successful genre production (especially Indianerfilme). While Barrandov was enjoying international recognition and festival and commercial successes, it gave DEFA the cold shoulder. During the same period, of course, the five Warsaw Pact allies also invaded Czechoslovakia (1968), and there were purges in the film industry

[4] See Barrandov Studios Archive, file "Strašná žena." Director of the Czechoslovak company Filmexport Ladislav Kvasnička straightforwardly commented on the importance the film industry ascribed to the colour material and the widescreen format and on the pragmatic approach towards co-productions: "The world market demands widescreen colour movies. The black and white classical format we still use for most of our output disqualify the movies commercially in advance. As long there will be the shortage of foreign currency for purchasing colour stock from the western countries, Filmexport will attempt to negotiate co-productions with western partners willing to provide us with the colour film stock." M. Fiala, "Dovoz a vývoz filmů ve světle faktů," Rudé právo 49, November 28, 1968, p. 5.

\section{Genre-boosting travellers}

[5] D. Wolf, Gruppe Babelsberg. Unsere nichtgedrehten Filme, VerlagNeues Berlin, Berlin 200o, pp. 47-49. [6] For more elaborated argument on the DEFA's demand for effective genre production as a motivation for the co-operation with Barrandov practitioners, see P. Skopal, "Reisende in Sachen Genre - von Barrandov nach Babelsberg und zurück. Zur Bedeutung von tschechischen Regisseuren für die Genrefilmproduktion der DEFA in den 1960er und 1970er Jahren," [in:] DEFA international. Grenzüberschreitende Filmbeziehungen vor und nach dem Mauerbau, eds. M. Wedel, et al., Springer Verlag, Wiesbaden 2013, pp. 249-266. 
and the launch of an ultra-conservative reaction called "normalisation." Predictably, political and cultural relations were strongly reserved until "normalisation" was launched in the Czech film industry in 1970.

Still these circumstances were not the only reason for the interruption in co-productions, nor did they mean that there were no contacts between East German and Czech filmmakers. The contrary was rather true. While DEFA was not happy with some of the problems that had emerged during previous co-productions, the studio had been eager to use the creative potential of Barrandov personnel, and invited Czech practitioners to launch new genre cycles of musicals and Indianerfilme in East Germany. As official relations chilled, these personal contacts persisted under the cold surface. The Künstlerische Arbeitsgruppe (KAG) Roter Kreis was particularly active in shooting genre movies with Czech participation. The group worked on Eine schreckliche Frau with the Czech artistic group Feix-Brož and, with the help of Czech director Josef Mach and Czech cameraman Jaroslav Tuzar, launched a super-successful series of Indianerfilme in 1965. The same director and cameraman also made another movie for Roter Kreis one year later (Der Schwarze Panther, 1966).

DEFA was actively searching for Barrandov practitioners to "outsource" its creative potential. Such practices, especially when applied to professions other than director, have not received much of attention from film historians to date. Tim Bergfelder used the term "commercial travellers" for film technicians moving as freelancers within Europe, mainly Berlin, Paris and London in the 1930s: one of the factors determining this development was the effort of European national film industries to differentiate their products in defence against Hollywood's hegemony. [7] Besides the evident differences in the situation of the socialist film industries (both East German and Czechoslovak film markets were protected against Western European and American competitors by strict screen quotas; moreover, the travelling practitioners were not real "freelancers," as they maintained their commitments to Barrandov and Prague's theatres), one analogy is obvious: they certainly were supposed to help DEFA to diversify its output and increase the attractiveness of its genre production for the audience. The attitude of DEFA to the creative potential of Czech filmmakers in the mid 196os resembles the relation of DEFA to West German practitioners in the 1950s, but with the significant ideological advantage of co-operation with a socialist country.[8]

One of the main incentives for using the Barrandov's personnel was a shortage of indigenous practitioners who would be willing or

[7] T. Bergfelder, “The Production Designer and the Gesamtkunstwerk. German Film Technicians in the British Film Industry of the 1930s," [in:] Dissolving Views. Key Writings on British Cinema, ed. A. Higson, Cassell, London-New York 1996, pp. 21-23.

[8] The participation of film practitioners from West Germany during the 1950 s was more extensive than the involvement of foreign filmmakers in the 196os; indeed, in the years $1951 / 52,44 \%$ of the studio's employees were living in West Berlin, and as many as 13 directors from West Berlin were still actively involved with Babelsberg in the mid-1950s. T. Heimann, DEFA, Künstler und SED-Kulturpolitik: zum Verhältnis von Kulturpolitik und Filmproduktion in der SBZ/DDR 1945 bis 1959, Vistas-Verlag, Berlin 1994, pp. 221-222. 
able to help the studio to produce the entertainment genre movies demanded by Central Film Administration (Hauptverwaltung Film - HV Film). It certainly was no coincidence that of the movies which passed the Kahlschlag in the GDR and were released in 1965 and 1966, very few had a strong genre identity - and, above all, seven were shot by a foreign director.[9] A report for HV Film about the DEFA production plan complained that the studio had a good supply of antifascist themes, but the share of entertainment genres, especially adventure movies and musicals, was minimal. According to the report, only Rolf Losansky and a few foreign directors were active in this kind of production, and "despite the fact that co-productions confirm that DEFA is an internationally recognized studio, co-productions cannot serve as an excuse for never-ending postponement in training indigenous experts, especially in entertaining movies and musicals." [10] This report can inspire us to re-evaluate the movie Eine schreckliche Frau, as well as subsequent projects using Czech creative workers, as a kind of professional training in producing entertainment, especially musicals and Indianerfilme.

The role of other Czech directors, actors, choreographers, cameramen and composers in various projects in the mid-196os support such a hypothesis. The Czech director Josef Mach launched a series of Indianerfilme with Die Söhne der großen Bärin in 1965, and then gave the role of director in the series over to indigenous filmmakers, although he also started work on the script for another Indianerfilm. Mach also directed Der Schwarze Panther (1966), an adventure movie set in a circus - an attractive setting which was not new to DEFA productions of the 1940s and 1950s. [11] Both of the movies were shot by the Czech cameraman Jaroslav Tuzar, whom Mach proposed for this job. Mach was explicitly chosen as a director who was experienced in genre productions and successful at attracting audiences: he was presented as an author of "comedies, satirical movies, and slapsticks," an adventure movie (Akce B), and a dance movie (Rodná zem), where he allegedly used stylistic devices taken from musicals[12] (in fact, the movie presents folk dances from Slovakia as part of a story about a group of enthusiastic folklorists). Moreover, Mach was proposed as the director for the comedy Ohne Pass in fremden Betten (1965) - but

[9] Five of the movies were shot by four Czech directors: Der Schwarze Panther (Josef Mach, 1966); Die Söhne der großen Bärin (Josef Mach, 1965); Ohne Pass in fremden Betten (Vladimír Brebera, 1965); Nichts als Sünde (Hanuš Burger, 1965), Eine schreckliche Frau. The remaining two pictures were co-productions with Yugoslavia (Ubica na odsustvu/Mörder auf Urlaub, Boško Bošković, 1965) and Bulgaria (Die antike Münze/Starinata Moneta, Vladimír Jančev, 1965).

[10] Stellungnahme zum thematischen Plan des DEFA, October 29, 1965 (BArch, DR 1/4935).

[11] 1-2-3 Corona (Hans Müller, 1948), Carola
Lamberti - Eine vom Zirkus (Hans Müller, 1954) and Alarm im Zirkus (Gerhard Klein, 1954) were significantly successful - 1-2-3 Corona reached 6 million viewers (H. Kersten, Das Filmwesen in der sowjetischen Besatzungszone Deutschlands, Bundesministerium für gesamtdeutsche Fragen, Bonn and Berlin 1963, p. 295), Alarm 3.6 million (E. Prommer, Kinobesuch im Lebenslauf. Eine historische und medienbiographische Studie, UVK Medien, Konstanz 1999, p. 348) and Carola Lamberti 6.3 million (BArch, DR 1/4921).

[12] BArch, DR 117/27724. 
the Roter Kreis group blocked the choice, fearing the KAG Johannisthal's project would limit the time and energy he could dedicate to the films he was making for them. The movie was made by another Czech director, Vladimír Brebera,[13] with music composed and performed by the Czech jazzman Karel Krautgartner and his orchestra. Mach handled his role as an entertainment genre booster rather effectively and pragmatically, as proven by both the enormous success of the first Indianerfilm with audiences and the complaints the author of the script and historian Liselotte Welskopf-Henrich raised against the director's use of suspense (Spannung).[14]

But the most significant role Czechs played in DEFA's plans was the role of boosters of the musical genre. Besides Eine schreckliche Frau, Czechs were also hired to participate in two other music films. Nichts als Sünde, was based on a successful theatrical adaptation of Shakespeare's comedy Twelfth Night, or What You Will. Hanuš Burger directed both the theatrical and the film version, and the actress Helga Čočková was casted in one of the lead roles. In 1964, the choreographer Josef Koníček worked on the highly successful and appraised Czech musical Starci na chmelu (dir. Ladislav Rychman) - DEFA admired the movie and hired Koníček as a choreographer for the musical Reise ins Ehebett (dir. Joachim Hasler, 1966), despite the troubles the appointment caused for DEFA due to Koníček's commitments to a Prague theatre.[15] The concluding report from the Johannisthal group for the movie noted that Koníček's participation was very important for DEFA's future projects in this genre[16] - we can retrospectively identify his influence on three of Johannisthal's subsequent popular hits: Heißer Sommer (1968) and Nicht schummeln, Liebling! (1972), both directed by Hasler and featuring Frank Schöbel (the role in Reise ins Ehebett was Schöbel's debut), and Hochzeitsnacht im Regen (dir. Horst Seemann, 1967), which was presented by the distribution company Progress as a proper accomplishment of socialist musical entertainment art (Unterhaltungskunst).[17]

By the end of 1960s, DEFA had already placed an emphasis on training and using its own creative personnel for genre productions. Such an approach corresponded to the above-mentioned signals from HV Film and gave the studio better control over the production process than would have been possible in the case of a hired foreign director.

DEFA and Barrandov in the 1970s:

a fairytale
Since Roter Kreis had succeeded so well in its work with Czech filmmakers up until 1966, it is not surprising that this artistic group then participated in three of the seven co-productions made during in the 1970s: Die gestohlene Schlacht with Miloš Brož's dramaturge
[13] See: BArch, DR 117/27649. Petr Schulhoff, the son of German composer Erwin Schulhoff, was also considered the director of the movie - it is almost self-evident that cultural and, above all, language affinity with Germany was an important factor in taking the decision about who could be chosen for the position of director.

[14] BArch, DR 117/27915.

[15] BArch, DR 117/33062.

[16] Ibidem.

[17] BArch, DR 117/27724. 
group, as well as Die Insel der Silberreiher and Der Katzenprinz, both with Hofman's children's movie dramaturge group. However, many things had changed in the interim, including the fact that Roter Kreis was no longer KAG, but a dramaturgical group.

Let us return to the main question: why is it that the studios once more began to work together so closely? I believe that we can identify reasons for the two film studios' re-alignment on three levels. First, there was the general political framework and ideological rapprochement of the GDR and Czechoslovakia: to identify the conditions of this rapprochement in the sphere of cultural policy, we must look at the cultural agreements that ensured the basic framework for co-operation. Relations between East Germany and Czechoslovakia had been worsening since the liberalization of Czechoslovak cultural policy in the mid-196os. Walter Ulbricht annoyed Czechoslovak leaders, including conservatives, by "raising [an admonishing] finger" against these liberal tendencies. [18] But the "normalisation" that took place after the August 1968 invasion put the regimes back in sync, as the cultural agreement signed in 1970 clearly indicates. This agreement refers to film at one point and bound the participants "to inform each other about any attempts on the part of the West German or American government [...] or other imperialist countries to launch ideological sabotage in the sphere of film, against the GDR, Czechoslovakia or other socialist countries." [19] In the 1970s, the GDR and Czechoslovakia were ideologically more aligned than they had ever been before, and no obstacles to cooperation in the domain of film came from above.

While such cultural agreements delimited the basic field of co-operation, a second level consisting of a network of personal contacts provided an essential pre-condition for viable collaboration. Such a network had been established during the previous "travelling practitioner" era, but had continued to be cultivated, as practitioners continued to visit each other and participate in exchanges, and German directors continued to be studied at FAMU. The first two of the 1970 s co-productions provide us with peculiar examples of this. The director of the first co-production of the 1970s, Erwin Stranka, was a Sudeten German, born in 1935 in the then-Czechoslovak city of Kadaň and expelled to Germany after the war. He studied at the FAMU film school in Prague from 1953 to 1959 and had witnessed one of the most appreciated co-operations of the "travelling Czech filmmakers" when he was an assistant director to Gerhard Klein on Der Fall Gleiwitz in 1961.[20]

[18] V. Zimmermann, "Proměnlivá spojenectví. NDR a její vztahy k Československu a Polsku v padesátých a šedesátých letech 2o. století," [in:] Československo a dva německé státy, eds. C. Buchheim, E. Ivaničková, K. Kaiserová, \& V. Zimmermann, Albis International, Praha 2011, pp. 83-98.

[19] Quoted in: I. Klimeš, "Koprodukce jako politikum. K pozadí vztahů mezi filmovými studii DEFA a
Barrandov po potlačení Pražského jara.” An unpublished manuscript.

[20] DEFA had not been limiting its search for creative support from Barrandov to the sphere of genre movies, as the former director of the studios Albert Wilkening confirms. His explanation of the reasons for hiring the Czech cameraman Čurík is telling: "The Czechs had the best cameramen then, they were 
Ralf Kirsten had also studied at FAMU from 1952 to 1956; he had turned to Prague with a request for assistance and co-production while working on the literary adaptation of Die Elixiere des Teufels. Of course, to a certain extent, the network was inevitably damaged by normalization, as some potential personal relations were interrupted by emigration and purges. The most important of these losses was when Vratislav Blažek, the scriptwriter for the DEFA movie Ach du fröhliche and the co-production Eine schreckliche Frau, emigrated to the "wrong" Germany. Nevertheless, most of the personal connections survived and were still functioning at the start of the 1970 s.

The most important and decisive factor contributing to a revival of DEFA-Barrandov co-productions was implemented on a third level consisting of mid-level work on concrete projects, in dramaturgical reasoning, and during the screenwriting process. In 1970, Barrandov underwent pervasive managerial and organizational changes. In March, the six "artistic groups" which had existed until then were dissolved and replaced by six dramaturgical groups and four production groups, a "reform" that aligned Barrandov with the structure in place at DEFA. The parallels to the changes which had taken place at DEFA just four years earlier are obvious. Quoting Mariana Ivanova:

In the aftermath of the 11th Plenary [...] the KAGs' growing artistic autonomy was curtailed and, by way of centralizing them, the groups were reorganized and renamed "dramaturgical groups" (Dramaturgengruppen), i.e. units managed by a dramaturge who reported regularly to the chief dramaturge and the studio's management.[21]

According to head dramaturge Ludvík Toman, the dramaturgical plans for the period after 1972 at Barrandov were supposed to be based on the directives of the 14th congress of the Czechoslovak communist party, which had instructed dramaturge groups to focus on movies which would help young people understand the policies of the state, make the struggle of the working class and the liberation from fascism more familiar to viewers, combat anti-communist influences, and illustrate the problems and the future of the scientific-technical revolution. After the first two co-productions, for which there was only minor participation on the part of Barrandov, Czech filmmakers had significant roles in another five movies, three of which more or less fit Toman's demand for ideologically-determined topics. These three films were Schüsse in Marienbad, Abenteuer mit Blasius and Die Insel der Silberreiher.

capable of imaginative work with the image. We took the fight against formalism too seriously in comparison, and our work with the camera was too rigid." An interview with Wilkening from 1984, quoted in: Birgit Schapowová, "Abseits ausgetretener Pfade - Der Fall Gleiwitz," [in:] DEFA international. Grenzüberschreitende Filmbeziehungen vor und nach dem Mauerbau, ed. M. Wedel, et al., Springer Verlag, Wiesbaden 2013, pp. 279-28o.

[21] M. Ivanova, DEFA and East European Cinemas: Co-Productions, Transnational Exchange and Artistic Collaborations. Ph.D. Diss., University of Texas, Austin 2011, p. 95. 
Schüsse in Marienbad tells the story of the murder of the German antifascist Theodor Lessing and the resulting post-war investigation. According to the dramaturgical explication, the movie should "help young people who do not have their own life-experience of fascism [...] to form progressive views." [22] Die Insel der Silberreiher deals with the increasing humanism, antimilitarism and "class consciousness" of three friends in Germany in 1918; while Abenteuer mit Blasius was allegedly meant "to provide children with entertainment, as well as with knowledge about the relationship between humans and machines...." [23]

Even if three of the five movies were rather mediocre in their commercial results and critical response, they still retained a certain standard, and two fairy-tales - Drei Haselnüsse für Aschenbrödel and Der Katzenprinz - were undisputed successes. What, then, helped keep the production level and aesthetic quality of these films above the muddy bottom of normalisation-era movies? I would like to suggest that the same conditions that appeared to be drawbacks in co-productions during the 1960s became advantages in the conservative era. In contrast to the 1960s, those Czech filmmakers and producers who survived the inspection of their ideological loyalty no longer held the prominent positions they enjoyed in the 1960s, and many scriptwriters were happy just to have something to work on. A co-production deal with a socialist country could ideologically support a project, and while mutual corrections and negotiations might not result in a brilliant piece of art, mutual demands assured that the movies produced remained above a certain level of quality. Indeed, in the case of Drei Haselnüsse für Aschenbrödel this mode of production resulted in a lasting classic. In other words, what worked well in the co-productions were not the new elements of the system, but, on the contrary, continuities with the 1960 s in the form of dramaturges who survived the purges (e.g., Miloš Brož, Ota Hofman) and scriptwriters who were able to work for the studio under their own, or someone else's name.

Besides scriptwriters, DEFA would certainly have welcomed collaborations with recognized Czech directors, but the studio was short of luck on this front. In the case of Drei Haselnüsse für Aschenbrödel, for example, the new wave director Jiří Menzel was briefly considered; but as he was still banned from directing (until he performed "self-criticism"),[24] Václav Vorlíček directed the film instead. Schüsse in Marienbad suffered a similar fate when Barrandov management did not allow František Vláčil, another recognized film-maker of the 1960 s, to direct the film. In contrast to directors, scriptwriters were less visible; after the structural changes went into effect, they became more

[22] An explication to the script. Barrandov Studios Archive, file "Výstřely v Mariánských Lázních." [23] A statement to the first version of the movie Dobrodružství s Blasiem. Babelsberg group, October 9, 1974. Barrandov Studios Archive, file "Dobrodružství s Blasiem."
[24] Letter from Ludvík Toman to the head of the Barrandov Studios Miloslav Fábera, May 10, 1972. Barrandov Studios Archive, file "Tř́i oříšky pro Popelku." 
detached from the process of filmmaking. In August 1970, a specific scriptwriters' department was established. While until then scriptwriters had usually worked on their own subjects, they now became processors of tasks and were separated from the dramaturge. These changes were supposed to help the chief-dramaturge, Toman, to control the evolution of a project.[25] But even blacklisted scriptwriters had a chance to work if they were covered by another name. This is what happened to František Pavlíček, who had worked as a dramaturge at Barrandov until the purges; Pavlíček was the one who wrote the script for Drei Haselnüsse für Aschenbrödel, though even the director did not know for a time that the real author was not Bohumila Zelenkova, to whom the script was officially attributed.

A few examples of individual decisions and mutual negotiations illustrate the essence of the relationships between DEFA and Barrandov, as well as the trust that DEFA invested in Czech scriptwriters. In the case of Die gestohlene Schlacht, the first version of the script proposed by DEFA was rejected by Barrandov, which insisted upon the right to approve proposed changes before moving ahead with the project.[26] Miloš Brož's dramaturgical group denied the first version of the script as unacceptable; the third version was the first which stuck to the conception proposed by the Barrandov dramaturges, which was finally embraced by both sides.[27] Ludvík Toman's complaints over the movies' dialogues interestingly highlight potential conflicts over the historical topic and its ideological implications - a problem which was certainly easier to avoid in the case of fairytales than in historical movies. Toman demanded a change in the dialogues in the finished movie for a number of reasons - he was afraid, e.g., that a critique of Prussianism, appropriate in the context of GDR, could be misunderstood by Czech audiences as being in conflict with internationalism.[28]

The same situation basically happened again with Die Elixiere des Teufels. As for Haselnüsse für Aschenbrödel, the project was initiated by DEFA, which argued that there was a demand for children's movies, but Hofman's group took over the initiative and Barrandov provided the script. When the successful Haselnüsse was finished, DEFA proposed a script entitled Modré $z$ nebe; but when Barrandov labelled it a chaotic piece, DEFA immediately withdrew the proposal.[29] In the case of Abenteuer mit Blasius, the DEFA script for the film was significantly rewritten by the Czech scriptwriter Milan Pavlík.[30]

[25] Š. Hulík, Kinematografie zapomnění, Academia, Praha 2011, pp. 146-151, 167.

[26] Three experienced dramaturges worked on the movie on the Czech side, including Věra Kalábová. She worked as a dramaturge on some of the most important new wave movies as well as on another co-production with DEFA, Die Insel der Silberreiher. [27] Letter from Miloš Brož to Ludvík Toman, March 22, 1971. Barrandov Studios Archive, file "Ukradená bitva."
[28] Letter from Toman to Bedřich Fronk, head of the Studio for foreign movies' arrangements, March 9, 1972. Barrandov Studios Archive, file "Ukradená bitva."

[29] Report of a journey, Eduard Hofman, January 1973. Barrandov Studios Archive, file "Tři oříšky pro Popelku."

[30] Letter from Hofman to the producer Z. Oves, June 12, 1974. Barrandov Studios Archive, file "Dobrodružství s Blasiem.” 
In conclusion, I would like to argue that while the end of independent production groups at DEFA and Barrandov certainly damaged the creative environment and the quality of productions as a whole, it also had an unforeseeable effect: namely, the revival of DEFA-Barrandov co-productions. On the German side, DEFA was interested in financial and technical support and, above all, in receiving help from experienced practitioners, especially scriptwriters. On the Czech side, Barrandov's filmmakers-now isolated from their previous contacts with western partners and under strict ideological control-strove to shape the DEFA projects they were offered according to their own criteria, where before they might have rejected projects they considered to be of dubious quality. There was thus a harmonization of goals and tools, which worked especially well in the sphere of children's movies. This was not only because this type of production were rarely hampered by divergent interpretations of the past by the two partners. There were two more important reasons as well: namely, that the dramaturge group for children's movies, headed by Hofman, was under looser ideological control by Barrandov management; and that the personal continuity with the pre-normalization era was stronger in this group than in other groups. This time, both studios were motivated to find an effective mode of co-operation. 